\title{
The Recruitment Process of the Head of Local Government by Political Parties In Malang Raya Region
}

\author{
Budhy Prianto \\ Department of Public Administration Science, the Faculty of Social and Political \\ Science \\ University of Merdeka Malang \\ Dwi Suharnoko \\ Department of Public Administration Science, the Faculty of Social and Political \\ Science \\ University of Merdeka Malang \\ Mardiyono \\ Department of Law, the Faculty of Law \\ University of Merdeka Malang
}

\begin{abstract}
Direct regional head elections are in the process of recruiting leaders in regions that can guarantee the representation of local people through a democratic process. In this process, theoretically and constitutionally political parties have important and strategic roles and functions. Unfortunately, the oligarchic practice that engulfed almost all political parties has internally and externally recognized the basic principles of democracy in the process of recruiting prospective leaders in the region. The democratic process is only procedural, not substantial. So far it is strongly suspected that the process of regional head elections is more colored by transactional politics. This paper aims first, to obtain an overview of the recruitment process of candidates by political parties in the regional head elections in the Malang Raya region. Second, to obtain a description that is the power of money not only in choosing candidates for the regional head, but also able to lull constituents and voters in determining the choice of regional heads. Third, to obtain an explanation of the impact of the transactional political process and the use of the power of money as well as the impact on the relationship between political parties and their constituents in the Malang Raya region.
\end{abstract}

Keywords: recruitment, election, political parties, local government, regional heads.

\section{INTRODUCTION}

Malang Raya was an area consisting of three regional governments, namely Malang Municipality, Malang Regency and Batu Municipality. The title of Malang Raya was popular when it begins its discourse to separate Batu as a separate local government. Some peoples argue that what was called "Malang Raya" was a cultural representation of the ex-Residency area of Malang which includes Malang Regency and Malang Municipality along with Batu Administrative Region, Probolinggo Regency and Probolinggo Municipality, Pasuruan Regency and Pasuruan Municipality, and Lumajang Regency. However, in subsequent developments this designation has narrowed to the cultural designation for culturally bound areas to the Arek Malang, Arema, and community such as Malang Regency, Batu Municipality, and Malang Municipality as well as parts of Pasuruan Regency (http://cakmaryono.com/malangraya/). In the political context, especially those relating to the process of articulation and aggregation of the interests of citizens in the area of Malang Raya show an interesting phenomenon. Political representation of the people of Malang Raya, which amounts to 3.5 million in political parties, is very diverse and fluctuating. This can be observed through the first, the acquisition of seats in political parties in the three regions in the 2009 and 2014 legislative elections. The details are shown in Table 1 below. 
Table 1. Acquisition of Political Party Seats in DPRD in the Greater Malang Region in the 2009 Election and 2014 Election

\begin{tabular}{|l|l|c|c|c|c|c|c|}
\hline \multirow{2}{*}{ No. Political Party } & \multicolumn{2}{|c|}{$\begin{array}{l}\text { Malang } \\
\text { Reg. }\end{array}$} & \multicolumn{2}{l|}{ Malang } & \multicolumn{2}{l|}{ Batu Mun. } \\
\cline { 3 - 8 } & & $\mathbf{2 0 0 9}$ & $\mathbf{2 0 1 4}$ & $\mathbf{2 0 0 9}$ & $\mathbf{2 0 1 4}$ & $\mathbf{2 0 0 9}$ & $\mathbf{2 0 1 4}$ \\
\hline \multirow{2}{*}{$\begin{array}{l}\text { Indonesian Democratic Party of Struggle } \\
\text { (PDI-P) }\end{array}$} & 13 & 13 & 9 & 11 & 5 & 5 \\
\hline 2 & Democratic Party & 8 & 3 & 12 & 5 & 3 & 3 \\
\hline 3 & Golkar Party (Golkar) & 8 & 12 & 5 & 5 & 2 & 3 \\
\hline 4 & National Awakening Party (PKB) & 8 & 8 & 5 & 6 & 2 & 4 \\
\hline 5 & Prosperous Justice Party (PKS) & 4 & - & 5 & 3 & 1 & 1 \\
\hline 6 & People's Conscience Party (Hanura) & 4 & 1 & 1 & 3 & 3 & 1 \\
\hline 7 & Gerindra (Gerindra) Party & 3 & 7 & 2 & 4 & 1 & 4 \\
\hline 8 & National Democratic Party (Nasdem) & - & 4 & - & 1 & - & 1 \\
\hline 9 & National Mandate Party (PAN) & - & - & 4 & 4 & 2 & 3 \\
\hline 10 & United Development Party (PPP) & 1 & 2 & - & 3 & - & - \\
\hline 11 & $\begin{array}{l}\text { Ulama National Awakening Party } \\
\text { (PKNU) }\end{array}$ & & & & & & \\
\hline 12 & Karya Peduli Bangsa Party (PKPB) & - & - & 1 & - & 1 & - \\
\hline 13 & Prosperous Peace Party (PDS) & - & - & 1 & - & - & - \\
\hline 14 & $\begin{array}{l}\text { Marhaenism Indonesian National } \\
\text { Party }\end{array}$ & & & & & & \\
& (PNIM) & - & - & - & - & 1 & - \\
\hline 15 & Patriot Party (PP) & - & - & - & - & 1 & - \\
\hline 16 & National Front Party (PBN) & - & - & - & - & 1 & - \\
\hline 17 & Karya Peduli Bangsa Party (PKPB) & - & - & - & - & 1 & - \\
\hline Number of Members & 50 & 50 & 45 & 45 & 25 & 25 \\
\hline
\end{tabular}

Source: District Election Commission Malang, Malang City, and Batu City.

Based on the data in Table 1 above, it can be seen that the acquisition of PDI-P, Golkar and PKB seats in three regions of Malang Raya are relatively stable. This can be used as an indication of a good relationship between the three political parties and the constituents or voters. However, several other political parties, such as PD, Gerindra, PKS, and PAN, and Hanura gained seats in the DPRD seemed to fluctuate, which was apparently caused by a shift in constituent support among the political parties. There are even a number of political parties that only existed in the 2009 elections, such as PNIM, $\mathrm{PP}, \mathrm{PBN}$, and $\mathrm{PKPB}$, and the latter political parties were only found in Batu Municipality.

Second, it relates to the process and results of regional head elections (pilkada). As be known, the two periods Malang Regent (2001-2005 and 2005-2010) Sujud Pribadi comes from PDI-P. However, in the following period, regent candidates from PDI-P can be defeated by candidates supported by Golkar who are coalition with PKB. The two periods Malang Mayor (2003-2008 and 2008-2013) Peni Suparto also came from PDI-P. However, similar to what happened in Malang Regency, in the next period the Malang Mayor Candidate who was supported by PDI-P also failed to compete with the mayor candidates who came from PKB. Only in Batu Munucipality PDI-P's domination over two periods (2007-2012 and 2012-2017) through Eddy Rumpoko could still continue in the next period with the election of Dewanty Rumpoko as mayor. 
Empirically it could be a change (fluctuation) and a shift in the map of constituent support for political parties is a consequence of the enactment of Law (UU) No. 32 of 2004 concerning Regional Government. In the case of regional head elections (Governor, Regent, and Mayor) Law No. 32 of 2004 stipulates at least two important matters relating to political party relations with constituents (article 56 and article 59). First, that the election of a pair of regional heads is democratically elected, which is then translated as direct election by the people or residents in the local area. Second, contestants in the election are pairs of candidates for regional heads proposed by political parties or joint political parties who obtain $15 \%$ of the seats in the DPRD or from the accumulation of legitimate votes in the previous legislative elections. The direct election of regional heads was first held on June 1, 2005. In the opinion of researchers, fluctuations and shifts in constituent support for political parties both in the 2009 and 2014 legislative elections resulted in seats in the DPRD, as well as in regional elections - in terms of this is the Regent of Malang in 2010 and 2015; Mayor of Malang in 2013 and 2018; and Mayor of Batu in 2012 and 2017 - due to at least two things. First, that in using voting rights, constituents are more likely to look at candidate pairs rather than see political parties where voters are affiliated. Second, the occurrence of fluctuations and constituent shifts indicates that the party machine is not working effectively, or in other words, this indicates a bad relationship between political parties and constituents.

This paper aims first, to obtain an overview of the recruitment process of candidates by political parties in the regional head elections in the Malang Raya region. Second, to get an idea that the power of money not only can influence the policy of political parties in choosing candidates for regional heads, but also able to lull constituents and voters in determining the choice of regional heads. Third, to obtain an explanation of the impact of the transactional political process and the use of the power of money in the election of regional heads on the welfare of the people in achieving the SDGs objectives, as well as the impact on the relationship between political parties and their constituents in the Malang Raya region.

\section{DISCUSSION}

\section{Recruitment and nomination process}

In accordance with the theories and laws that apply in the electoral process the role and function of political parties is to recruit candidates for public officials, be they presidents, governors, regents / mayors, as well as legislators at the national or regional level. In carrying out this recruitment political parties are required to listen to the voices of the community (Cummings and Wise, 1981: 221) are also intended to select and produce qualified and nationally minded leaders (Firmanzah, 2008: 70). Recruitment and selection of candidates according to Scarrow (2005: 7-8) is a crucial task for political parties, because the appearance of the party during the election and at the time of office is more determined by how the process of selecting candidates and where their loyalty is tied. Parties that wish to include a broad circle of supporters in this process usually rely on one of two ways: whether through direct elections among eligible supporters, often referred to as primary elections, or through nominations by a kind of party council. The latter can be a comprehensive council (in the form of a caucus) or in the form of a representative council formed for this purpose. Which procedure will be used, the party must still decide on candidates who meet the requirements. Generally the party will prioritize party members, even though it also opens opportunities for any interested supporters. It's just that this overly open procedure will open up opportunities for infiltration by people who are not in line with the party's vision or ideology, or there is even the possibility of active resistance from people like this. 
To strengthen the democratization of political parties in the selection of legislative candidates and party leaders Norris (2004: 24) suggests that the decisionmaking process be decentralized by involving grass root activists. For this purpose Norris developed a schematic model to identify the main factors influencing the candidate recruitment process. This model proposes three stages of the process working sequentially: certification (certification) includes electoral laws, party rules, and social norms that informally limit nomination requirements criteria; nominations (nominations) include requests for candidates who meet the requirements as needed and offers from the selector to determine who deserves to be nominated; and election, the final stage of determining who is the legislative official's nomination. Each stage can be seen as a progressive game 'musical choirs': many are eligible, few are nominated, and fewer are successful.

\section{Certification process}

In contrast to the era of direct democracy which does not require representative institutions that function to channel interests, demands, and public support to governments that have decision-making authority, modern political systems in the era of nation-state desperately need political parties (Agustino, 2007: 100; Amal, 1988 : xi). The existence of political parties is very necessary so that a modern government can work well, even according to Norris (2005: 3), without a political party the modern representative democratic system cannot work perfectly. The importance of the political party is shown by a number of functions that must be carried out. These functions include the function as a means of political communication, as a means of political socialization, as a means of political recruitment, and as a means of regulating conflict (Budiardjo, 2008: 405-409). Opinions that are not much different are expressed by Shively (1991: 172) that the political party must do the following: a basis for the mobilization of masses of citizens; a means of recruiting and socializing political leaders; structured political identity, at both mass and elite levels; and a method of control within a government structure.

Regarding the important role of political parties in the democratization process, in his study of democracy in Indonesia Liddle (1992: 143-144), it was emphasized that a system of government that is simultaneously democratic, effective and stable in the third world including in Indonesia must have political parties that: (1 ) through overlapping electoral processes, selecting officials who are formally (constitutionally) and informally (conduct) responsible for decision making on state policies; (2) is free from other forces, especially personal rulers, bureaucrats or the military; (3) overall have broad support in the community; and (4) relying on leadership that is trusted by its members and is considered by the general to be able to lead the country. The exercise of the right to elect the government and these officials according to International IDEA (2000: 58) requires awareness of political parties as representative instruments and participatory democracy. The composition of elected representatives must be in proportion to the results of the vote. For this reason the electoral system that might be adopted is proportional representation and regional representation. 
What was put forward by International IDEA turned out to be later in line with the electoral rules - specifically for regional head elections - contained in the Law of the Republic of Indonesia (UUD RI) Number 12 of 2008 which was a amendment to the Law of the Republic of Indonesia (RI Constitution) Number 32 of 2004, specifically article 56, which regulates every contestant (candidate pair) in the election is required to use a vehicle in the form of a political party or a combination of political parties. In addition, the article states: (1) Regional heads and deputy regional heads are elected in one pair of candidates which are carried out democratically based on the principle of direct, public, free, confidential, honest and fair; (2) The candidate pair as referred to in paragraph (1) is proposed by political parties, joint political parties, or individuals who are supported by a number of people who fulfill the requirements as stipulated in this Act. Pilkada is a subsystem of elections in Indonesia whose main purpose is to transfer of power, from top level to lower level (Hidayat, 2000). In essence, a political decentralization is created from the center to the regions. Then the question, why do you have to go through the election? Not appointed directly by the President, or DPRD. This will return to the legitimacy of the power in the form of popular sovereignty, one of which is realized in direct elections. Regarding the legal basis, the election was first known in Article 24 paragraph (5) of Law No. 32 of 2004 concerning Regional Government which states that the Regional Head and Deputy Regional Head are elected in one pair directly by the people in the area concerned. There is also in article 56 "Regional heads and Deputy Regional Heads are elected in one pair of candidates that are carried out democratically based on the principle of direct, public, free, confidential, honest and fair." But with the birth of Law No. 22 of 2007 concerning the implementation of elections has revised the provisions the organizer in Law No. 32 2004. Law No. 22 of 2007 placed the election as part of the election regime so that the KPU with its independence was responsible for organizing the elections. The second amendment to the Act. No. 32 of 2004 set forth in Law No. 12 of 2008 also has made a substantial revision of the implementation of the election, especially in accommodating the presence of individual candidates, as a result of constitutional corrections made by the public who only allow nomination through political parties. There are still opportunities for the emergence of national leaders from below and / or regions. There are also a number of arguments on the importance of the elections, which among others are to improve the quality of accountability of local political elites, to create political stability and the effectiveness of governance at the local level, to strengthen and improve the quality of national leadership selection because there are still opportunities for the emergence of national leaders from below. and / or regions. The last is as a place where local communities channel their political aspirations to choose local leaders according to their respective consciences.

The things that must be fulfilled that want to nominate regional heads with independent channels are as intended in Article 40 Paragraph (1) of Law Number 10 of 2016 concerning the Second Amendment to Law Number 1 of 2015 concerning the Establishment of Government Regulations in Lieu of Law Number 1 of 2014 concerning the Election of Governors, Regents, and Mayors Becomes Law, which states that: Political Parties or a combination of Political Parties can register a candidate if they meet the acquisition requirements of at least $20 \%$ (twenty percent) of the total seats of the House of Representatives Regional People or $25 \%$ (twenty five percent) of the accumulation of valid votes in the general election of members of the Regional People's Legislative Assembly in the region concerned. 


\section{NOMINATION}

The scope of the discussion of this paper is the process of recruiting candidates for regional heads in Malang since the direct election took place in 2005. That same year in Malang Regency the first direct election was held. For Batu Municipality, the direct local election was held for the first time in 2007, while for Malang Municipality it was held in 2008. Furthermore, the description of the process of recruitment of regional heads in the three regional governments in the Malang Raya region was as follows.

\section{Malang Regency}

The election of the regional head (regent and vice regent) directly in Malang Regency for the period 2005-2010 was won by the Sujud Pribadi pair (incumbent regent) who paired with Rendra Kresna who was a member of the DPRD of Malang Regency. The pair was nominated by the party from Sujud Pribadi, PDIP which had a coalition with the party from Rendra Kreshna, Golkar. In the 2010-2015 regional election, Sujud Pribadi did not allow to run again, because he had served two terms. Meanwhile, Rendra Kresna was then promoted by Golkar as a candidate for regent paired with Subhan as the deputy regent who was carried by the Democrats and then supported by PKS and PPP. Compete with the partner Geng Wahyudi-Abd. Rahman carried by PDIP and PKB and with Agus Wahyu Arifin-Abd. Mujib Syadzilli, who was carried by Gerindra, Hanura, and PKNU, the Rendra-Subhan pair finally won the Malang Regency election contest for the 2010-2015 periods.

In the election of Malang regent-vice-regent for the period of 2015-2020, Rendra Kreshna ran again as a candidate for incumbent regent who paired with Sanusi. It's just that for this second term of office Rendra is no longer carried by Golkar, but through Nasdem. The jumping of Rendra to Nasdem was caused not only by the conflict at the Golkar central leadership level, which resulted in the lack of immediate decision regarding Rendra's candidacy, also caused by Rendra who felt that he was no longer fit to remain in Golkar. These two reasons are often used to dismiss allegations of political dowry from Nasdem to Rendra or Golkar (Tempo, 15 March 2015). This was also reinforced by the statement of one of the Golkar DPD leaders in Malang Regency:

In terms of nomination in the elections, we have never recruited figures from outside Golkar. But it is precisely our cadres that are often taken by other political parties. For us it doesn't matter, it shows that we have many qualified cadres. Rendra is one of the best Golkar cadres. And we believe Nasdem took Rendra because of that, not because of transactional politics.

While Sanusi was carried by PKB. This pair on his trip was also supported by PPP, Gerindra, Democrats and PKS. Later, Golkar also gave support to this couple. RendraSanusi's partner in the 2015 elections had to compete with two other couples, namely Dewanti Rumpoko-Masrifah, both of which were carried by PDIP. While the other pairs came from individual groups (independent), namely the Nurcholis-Mufidz pair. 


\section{Batu Municipality}

The election of the mayor-deputy mayor of Batu in 2007 was held on 25 October 2007 following the death of Mayor of Batu Imam Kabul. This agenda was held before 100 days of the death of Imam Kabul. The Mayor and Deputy Mayor Candidate pairs enlivened the elections, namely Eddy Rumpoko-Punjul Santosa (PDIP), SuhadiZen Achmad (Golkar, PKB, and PAN), Suharnanto-Andrek Prana (Democrat), Achiyadi-Dwi Sudarto (Gulo Klopo Coalition from 14 parties), Khudori-Suyitno (National religious coalition of 6 parties). However, Batu Election Commission (KPU) was considered too brave to continue the pilkada stages after the death of Mayor Batu Imam Kabul. Because the community hopes, the KPU postpones the election until the minimum period of mourning is 100 days, so that it has enough time to determine the expected leader. By continuing the election process, an activist in the city of Batu gave a comment,

Whoever the winner will be, it is not a victory for the citizens of Batu City. But it is a victory for political brokers and political parties.

The Eddy Rumpoko-Punjul Santosa pair then won the contest of the election of the mayor and deputy mayor of Batu for the period 2007-2012.

In the 2012 regional head election Eddy Rumpoko-Punjul Santoso advanced again as a pair of incumbent mayor and vice mayor candidates. Eddy Rumpoko-Punjul Santoso's pair was challenged by three other couples, namely the couple Abdul MajidKustomo (individual candidates), Suhadi-Suyitno (Golkar and PKB), and Gunawan Wirutomo-Sundjojo (Hanura and PKNU). In this period election problems arose when the KPU crossed out and annulled Eddy Rumpoko-Punjul Santoso. This is due to the existence of new requirements that are different from the requirements that apply to the selection of the previous 2007 period. The difference in the requirements lies in that in the previous period each candidate was only required to attach the last certificate he had, while the requirements for the 2012 period required each candidate to attach all the diplomas they had. Based on public reports which were then continued by KPU investigation, it was proven that Eddy Rumpoko's junior high school diploma was fake (Republika, 08/10/2012). Not accepting the KPUD's decision, Eddy Rumpoko sued to the court, which ultimately the court won. Based on the court's decision, the KPUD then revoked the withdrawal of the couple Eddy Rumpoko-Punjul, and returned to include him in the election contest. At the presentation of the vision and mission in front of the DPRD of Batu Municipality Eddy Rumpoko explained, the vision conveyed was a summary of the tenure he held for the past five years. In his speech, Eddy said that he would build Batu City as an international tourism-based organic farming center, involving farmers and tourism actors in Batu. As well as building ASEAN Park which contains culture, crafts and parks characterized by ASEAN Countries (Kompas, 4/12/2012). 
In the 2017 elections held on February 15, 2017 to elect the Mayor and Deputy Mayor of Batu for the period 2017-2022. Batu Municipality's KPU determines four pairs of Batu Mayor and Deputy Mayor Candidates who will fight. The four pairs of candidates are independent candidates Abdul Majid-Kasmuri Idris; Hairuddin-Hendra Angga Sonata carried by PKB and Democrats; Dewanti Rumpoko-Punjul Santoso supported by PDIP, Golkar, Gerindra, and PKS; and Rudi-Sujono Djonet proposed by PAN, Nasdem, and Hanura. One of the things that had been constrained when the requirements verification process was a matter of name. The name Dewanti Rumpoko is not the same as the name on the diploma and KTP. The problem was finally resolved by the determination by the court and agreed to use the name Dewanti Rumpoko (Kompas, 10/24/2016). Dewanti was the wife of Batu Mayor Eddy Rumpoko. Dewanti Rumpoko was able to run for the Malang Regency head election in 2015, but failed. Based on the Decision of the KPU of Batu Municipality Number 22 / HK.03.1-Kpt / 3579 / KPUK0ta / 1V / 2017, dated April 5, 2017 the Dewanti Rumpoko-Punjul Santoso pair was declared the winner in the election contest (Surya, 16/2/17). Dewanti's victory has been predicted by many parties. This is based on the Batu community's assessment of the success of her husband, Eddy Rumpoko in leading the Batu Municipality administration for two periods (Kompas, 6/24/2015). In addition, the victory of Dewanti in Batu Municipality was also caused by the hard efforts of PDIP after experiencing defeat in Malang Municipality and in Malang Regency. The harshness of the effort was marked by the removal of Eddy Rumpoko from his position as Chairperson of the PDIP Branch Board of Malang Regency, with the aim that Eddy could concentrate on maintaining the domination of PDIP in Batu region (Surya, 2/10/2016). However, all of Eddy Rumpoko's achievements were destroyed, while waiting for his wife's inauguration, Dewanti, to replace him as the mayor of Batu, the KPK was arrested on charges of corruption (KONTAN.CO.ID, 17 September 2).

\section{Malang Municipality}

The General Election Commission (KPU) of Malang Municipality officially stipulates five candidate pairs of mayor and deputy mayor of Malang as participants of the Malang Municipality elections in 2008. They also signed a joint agreement to hold peaceful elections. The determination of the five candidate pairs was set forth in the official report Number 270/32 / BA

/ 35.73.800 / 2008 concerning the determination of the serial number of the candidate pairs of regional heads and deputy regional heads of Malang Municipality in 2008. The five candidate pairs were respectively R. Aries Pudjangkoro-Mohan Katelu (GolkarPAN), Fathol Arifin-Subur Triono (PKB), Peni Suparto-Bambang Priyo Utomo (PDIP), Hasanudin Abdul Latief-Arief Darmawan (Democratic Party), and Ahmad SubchanNoor Chozin Askandar (PKS) (Kompas, 16/06/2008).

In the Malang Municipality election in 2013, this was held on May 28, 2013 to choose Malang's mayor and deputy mayor for the 2013-2018 periods. In this period's election, Malang Municipality Election Commission (KPU) established six pairs of Malang Mayor 2013 election candidates on April 2, 2013. The six pairs were Dwi Cahyono-Muhammad Nuruddin from independent channels; Sri Rahayu-Priyatmoko Oetomo carried by PDIP; Heri Pudji Utami-Sofyan Edy Jarwoko carried Golkar, PAN, and 15 non-parliamentary political parties; Ahmad Mujais-Yunar Mulya from an independent path; Agus Dono Wibawanto-Arif Hari Setiawan, carried by Democrats, PKS, Hanura, and non-parliamentary parties, PKPB; and mate Moch. 
Anton-Sutiaji nominated by PKB and Gerindra

(http://www.wikiwand.com/id/Pemilihan_umum_Wali_Kota_Malang_2013). What makes this period pilkada a hot situation and invites the attraction of people to observe and feel concerned was first, the emergence of the figure of Moh. Anton, a businessman as a candidate for mayor who was promoted by Gerindra, who later also supported PKB. Remembering Moh. Anton, who has an entrepreneur background and was considered to lack experience in the field of government, then raises questions about the existence of political transactions between Moh. Anton with the two political parties supporting him. This question is at least as stated by an activist in Malang:

We know what the character of the entrepreneur is, and what kind of political behavior Gerindra is like, what is the behavior of the central leadership of PKB. Moreover, then there was the fact that once elected as mayor, the PKB Central Leader immediately appointed Moh. Anton as the Head of Malang City PKB Tanfidziyah without the deliberation at the Malang City level. So if there are people who suspect that there is a political transaction transaction, it could be.

Second, there was a split within the PDIP. This was due to the fact that in the post-era era, political power reform in Malang Municipality was dominated by PDIP. The split began with Heri Puji Utami who was the wife of the mayor and concurrently Chairman of the Malang Municipality DPC PDIP at the time, namely Peni Suparto did not get a recommendation from the PDIP Central Executive Board (DPP) to advance as a candidate for Malang mayor. The recommendation of the PDIP DPP was only directed at the Sri Rahayu-Prijatmoko Oetomo pair. The decline in recommendations to the Sri Rahayu-Prijatmoko candidate pair coincided with the decision to dismiss Peni Suparto from his position as Chairman of the Malang Municipality PDIP DPC, because he was deemed disobedient to the central leadership's decision. The PDIP Central Executive Board then appointed Eddy Rumpoko as Chief Executive of the Malang Municipality PDIP DPC (Kompas, 02/17/2013). Peni Suparto who felt he still had the mass from the 'red' carriage then formed the Red Army. Whereas Heri Puji Utami, then carried by a coalition of several parties including Golkar which placed Sofyan Edi Jarwoko as a candidate of the deputy mayor. Heri Puji Utami's pair-Sofyan Edi Jarwoko at that time finally became a formidable opponent of Sri Rahayu-Prijatmoko Oetomo. The split within the Malang Municipality PDIP was confirmed to have resulted in the outbreak of constituent support that had been obtained by PDIP. This situation was used by the couple Moh. Anton-Sutiaji carried by Gerindra and PKB. Moh. Anton-Sutiaji finally won the regional head election of Malang Municipality and will occupy the Mayor and Deputy Mayor seats for the 2013-2018 period. However, not long after being elected Mayor of Malang, Moh. Anton actually left his bearer party, Gerindra. Moh. Anton joined the PKB, and was even officially appointed as Chairman of the Tanfidziyah DPC PKB of the Malang Municipality by the PKB DPP on February 19, 2014. According to M Syafik, the Chairman of Tanfidziyah DPC PKB Malang City the process of replacing Anton was considered unusual, because it was appointed directly by the PKB DPP, not through election process, especially the period of office of M. Syafik, remains a long time, until 2018 (Kompas, 02/24/2014). 
In the process of implementing the Malang Municipality Election for the period 2018-2023, the KPU of Malang Municipality on February 12, 2018 determined three pairs of candidates for Mayor and Deputy Mayor of Malang City in an open plenary meeting at the Ijen Suites Hotel, Malang City. The three pairs of candidates are M Anton-Syamsul Mahmud, carried by PKB, PKS, Gerindra; Yaqud Ananda QudbanAhmad Wanedi was carried by PDIP, PAN, Hanura, PPP; and Sutiaji-Sofyan Edi Jarwoko who was carried by Golkar and Democrats. The three pairs of candidates were determined by Decree Number 4 / HK.03.1-KPT / 3537 / KPT / KOP / II 2018.

Of the three candidates who have registered with the KPU, they are indeed not foreign figures anymore. Some were old figures who have participated in the fight five years earlier, namely M. Anton, Sutiaji, and Sofyan Edi Jarwoko. As be known, Anton and Sutiaji five years ago was a couple who managed to win the election contest in 2013. This year, both of them came back again, but not as a couple, but as a competitor to compete for the seat of the Mayor of Malang. Meanwhile, Sofyan Edi Jarwoko, previously held by the wife of Peni Suparto, Mayor of Malang for the period 20032013, Heri Pudji Utami, in the contestation in 2013. During this period, the Chairman of the Golkar DPD was nominated to accompany Sutiaji.

While three other names, namely Yaqud Ananda Gudban, Ahmad Wanedi, and Syamsul Mahmud were indeed familiar in the political arena of Malang Municipality. The three were cadres from the Hanura party, PDIP, and PKS. They were indeed the first time registered as contestants in Malang Municipality election competition. In the period of 2018, this phenomenon was quite interesting, especially experienced by PDIP. In the 2013 election period, PDIP was still in an atmosphere of internal conflict with confidence without coalition with other parties, and failed. But this year, perhaps not wanting to repeat the failure in 2013, PDIP chose to join a large coalition to support the Yaqud Ananda Gudban-Ahmad Wanedi pair. In the big coalition PDIP, Hanura, PAN, and PPP joined as the bearer party. While the Nasdem who initially as the bearer party were crossed out and only used as supporting parties. During this period, Golkar also no longer cooperated with PAN as in 2013, but preferred to join hands with Democrats to carry out Sutiaji and Sofyan Edi Jarwoko. Likewise with Democrats who were previously a coalition with Hanura and PKS, in this period they preferred with Golkar. While the PKB and Gerindra, in this period still chose together as they had done in the previous five years. This coalition was also strengthened by the PKS to carry M. AntonSyamsul Mahmud.

What shocked the public was that in the middle of the Election Day the KPK had set Mochamad Anton and Yaqud Ananda as bribery suspects to smooth the discussion of the Amended Regional Expenditure Budget (APBD-P) for the 2015 fiscal year. Anton was the Mayor of Malang 2013-2018, while Yaqud was a member of the DPRD of Malang Municipality for the period 2014-2019 (Tempo, March 21, 2018). The Panel of Judges of the Surabaya Corruption Court finally sentenced the non-active Mayor of Malang to Muhammad Anton for two years in prison. In addition, Anton was fined Rp. 200 million for four months in prison, and his political rights were revoked for two years after serving his sentence (antaranews.com, 08/10/2018). This situation is considered by many to be one of the beneficial factors for the Sutiaji-Sofyan Edy Jarwoko couple who later won the regional head election of Malang Municipality (Surya, 5/7/2018). 


\section{IMPACT}

As the above has described the description of the regional head recruitment processes through a selection process in each political party which was then followed by the electoral process through direct regional head elections. From the process it can be seen that Rendra Kresna was able to lead the Malang Regency Government since 2010 without any apparent turmoil. In Batu Municipality, Eddy Rumpoko was able to survive exactly for two periods 2007-2012 and 2012-2017, which based on the data showed success in creating Batu as a City of Tourism, although at the end of his tragic term he was arrested by the KPK. While, Moh. Anton, when he almost finished the first period of his term and tried to progress again in the regional head elections for the second period, he was arrested by the KPK and then the court decided he was imprisoned for two years.

What was the performance of the three regional heads in Malang Raya during their term of office, here was tried to be assessed using three parameters, namely the Percentage (\%) of the Original Regional Income (PAD) against the Balancing Fund (DP); Fiscal Capacity Index (IKF); and the Human Development Index (HDI). First, the percentage $(\%)$ of PAD on DP in this case was intended by the researcher to be able to at least two things, the size of the level of dependence of the regional government on the balance funds, and the ability of the local government to explore and improve PAD. Based on the data collected for 2013-2016, on the average of the percentage of PAD on the Malang Regency DP was $21.01 \%$; Malang Municipality amounted to $40.74 \%$; and for Batu Municipality $16.21 \%$. More can be seen in Table 2 below.

Table 2: Percentage (\%) of PAD over Balancing Funds in the Greater Malang Region 2013 - 2016 (Billion)

\begin{tabular}{|c|c|c|c|c|c|c|c|c|c|}
\hline \multirow{2}{*}{ Year } & \multicolumn{3}{|c|}{ Malang Regency } & \multicolumn{2}{|c|}{ Malang Municipality } & \multicolumn{3}{c|}{ Batu Municipality } \\
\cline { 2 - 11 } & PAD & DP & \% & PAD & DP & \% & PAD & DP & \% \\
\hline 2013 & 262,26 & 1700,48 & 15,42 & 313,77 & 863,74 & 36,33 & 59,67 & 446,59 & 13,36 \\
\hline 2014 & 411,19 & 1832,00 & 22,44 & 372,55 & 956,69 & 38,94 & 78,29 & 489,84 & 15,98 \\
\hline 2015 & 461.89 & 1893,23 & 24.40 & 424,94 & 926,36 & 45,87 & 99,73 & 554,90 & 17,97 \\
\hline 2016 & 502.75 & 2308,27 & 21,78 & 447,33 & 1069,37 & 41,83 & 109,53 & 624,42 & 17,54 \\
\hline
\end{tabular}

Source: processed from the Central Bureau of Statistics Malang Regency; Malang Municipality, and Batu Municipality

Note: $\mathrm{PAD}=$ Regional Original Income; DP = Balancing Fund

Second, Fiscal Capacity Index (IKF) according to the Regulation of the Minister of Finance of the Republic of Indonesia Number 54 / PMK.07 / 2014 concerning Regional Fiscal Capacity Map, especially in article 1 (1) fiscal capacity is a description of the financial capacity of each region reflected through general revenue Regional Revenue and Expenditure Budget (excluding special allocation funds, emergency funds, old loan funds, and other revenues whose use is limited to financing certain expenditures) to finance government duties after deducting personnel expenditure and associated with the number of poor people. The data collected by the researchers shows that for Malang Regency Government during 2014-2016 was in the Low category, while in the next two years, namely 2017 and 2017 it jumped into the Very High category. For the Malang Municipality Government, in 2014-2016 they were in the Medium category and in the last two years, namely 2017 and 2018 increased to the High category. The opposite condition occurs in the Batu Municipality Government, which in 2014-2016 was in the High category, but in 2017 it dropped to the Low category, and in 2018 it increased slightly in the Medium category. More can be seen in Table 3 below. 
Table 3: Fiscal Capacity Index in Malang Raya 2014-2018

\begin{tabular}{|c|c|c|c|c|c|c|}
\hline \multirow{3}{*}{ Year } & \multicolumn{2}{|c|}{ Malang Regency } & \multicolumn{2}{c|}{$\begin{array}{c}\text { Malang } \\
\text { Municipality }\end{array}$} & \multicolumn{2}{c|}{ Batu Municipality } \\
\cline { 2 - 7 } & Index & Category & Index & Category & Index & Category \\
\hline $2014^{\mathrm{a}}$ & 0.11 & Low & 0.55 & Medium & 1.36 & High \\
\hline $2015^{\mathrm{b}}$ & 0.13 & Low & 0.70 & Medium & 1.29 & High \\
\hline $2016^{\mathrm{c}}$ & 0.22 & Low & 0.97 & Medium & 1.92 & High \\
\hline $2017^{\mathrm{d}}$ & 2.71 & Very High & 1.54 & Height & 0.71 & Low \\
\hline $2018^{\mathrm{e}}$ & 2.08 & Very High & 1.61 & Height & 0.84 & Medium \\
\hline
\end{tabular}

\section{Source:}

aRegulation of the Minister of Finance of the Republic of Indonesia No. 54 / PMK .07 / 20 14

${ }^{\mathrm{b}}$ Regulation of the Minister of Finance of the Republic Of Indonesia No 33 /

PMK.07 / 2015 Regulation of the Minister of Finance of the Republic Of Indonesia No 37 /PMK.07 / 2016 Regulation of the Minister of Finance of the Republic Of Indonesia No 119 / PMK.07 / 2017 Regulation of the Minister of Finance of the Republic Of Indonesia No 107 / PMK.07 / 2018

Third, the Human Development Index (HDI). The Human Development Index has three dimensions that are used as a basis for calculation: (1) Longevity and healthy life as measured by life expectancy at birth; (2) Knowledge calculated from school expectations and the average number of years of schooling; and (3) A decent standard of living calculated from Gross Domestic Product / GDP (balance of shopping ability) per capita. According to the Central Statistics Agency (BPS), the Human Development Index (HDI) has several benefits: (1) HDI is an important indicator to measure success in efforts to build the quality of human life (community / population);

(2) the HDI can determine the ranking or level of development of a region / country; (3) For Indonesia, the HDI is a strategic data because in addition to being a measure of Government performance, the HDI is also used as one of the allocators for determining the General Allocation Fund (DAU). If made the average HDI in the three regional governments in Malang during 2011-2017 shows the Malang Municipality Government has the highest average HDI, which is 79.13, then below it is the HDI of Batu Municipality Government of 72.04, and the lowest is the Malang Regency Government with an average HDI of 66.01. More can be seen in Table 4 below.

Table 4. Human Development Index in Malang Raya (2011-2017)

\begin{tabular}{|c|c|c|c|}
\hline \multirow{2}{*}{ Year } & \multicolumn{3}{|c|}{$\begin{array}{c}\text { Human Development } \\
\text { Index }\end{array}$} \\
\cline { 2 - 4 } & & & \\
& Malang Municipality & Batu Municipality & Malang Regency \\
\hline 2011 & 77,36 & 69.76 & 63.97 \\
\hline 2012 & 78.04 & 70.62 & 64.71 \\
\hline 2013 & 78.44 & 71.55 & 65.2 \\
\hline 2014 & 78.96 & 71.89 & 65.59 \\
\hline 2015 & 80.05 & 72.62 & 66.63 \\
\hline 2016 & 80.46 & 73.57 & 67.51 \\
\hline 2017 & 80.65 & 74.26 & 68.47 \\
\hline
\end{tabular}

Source: Central Bureau of Statistics of Malang Municipality, Batu Municipality, and Malang Regency 


\section{CONCLUSION}

First, the process of selecting candidates for regional heads / deputy regional heads in Malang Raya had been through nominations in each political party. The results of the nomination were then continued at the electoral stage in the regional head elections (pilkada) held by the General Election Commission (KPU) of each region. Secondly, at the stage of nomination of candidates for regional heads internally in political parties there was a tendency for friction between central party leaders and local political party leaders in the Malang Raya region. This friction resulted in the emergence of internal conflicts of political parties, which brought about the failure of the election of the party candidate concerned to occupy the chair of the head / deputy regional head. Third, even though there were allegations of transactional politics between candidates for regional heads and political parties carrying them or between political parties, the allegations were not supported by concrete data. Fourth, the selection process for the head of local governments in the Malang Raya area tends to be less consistent with the performance of the government, especially those relating to PAD, IKF, and HDI. Fifth, the relationship between political parties and constituents tends to be more determined by leaders of political parties at the local level than by leaders at the central level. A less harmonious relationship between the central leadership of political parties and local leaders results in a lack of constituent support for candidates supported by the political parties concerned.

\section{REFERENCES}

Agustino, Leo, 2007, Perihal Ilmu Politik Sebuah Bahasan Memahami Ilmu Politik, Yogyakarta, Penerbit Graha Ilmu

Amal, Ichlasul, 1988, Pengantar, dalam Amal, Ichlasul (editor), Teori-Teori Mutakhir Partai Politik, Yogyakarta, PT Tiara Wacana Yogya

Ambardi, Kuskridho, 2009, Mengungkap Politik Kartel, Studi tentang Sistem Kepartaian di Indonesia Era Reformasi, Jakarta, Penerbit KPG (Kepustakaan Populer Gramedia) bekerjasama dengan Lembaga Survei Indonesia

Budiardjo, Miriam, 2008, Dasar-Dasar Ilmu Politik, Edisi Revisi, Jakarta, Penerbit PT Gramedia Pustaka Utama

Buehler, Michael, and Tan, Paige, 2007, Party-Candidate Relationships in Indonesian Local Politics: A Case Study of The 2005 Regional Elections In Gowa, South Sulawesi Province, Journal INDONESIA, New York, Penerbit Royal Institute of Linguistics and Anthropology, www.columbia.edu/cu/weai/pdf/Party_Buehler.pdf

Cumming Jr, Milton C dan Wise, David, 1981, Democracy under Pressure an Introduction to the American Political System, Fourth Edition, New York, Harcourt Brace Jovanovic, Inc.

Dhakidae, Daniel, 2009, Partai Politik di Persimpangan Jalan, dalam, Prisma Majalah Pemikiran Sosial Ekonomi, Penerbit LP3ES, No. 1, Vol. 28, Juni

Diamond, Larry, 1999, Developing Democracy: Toward Consolidaiton, Maryland: John Hopkins University Press. diterjemahkan IRE Press Yogyakarta, 
DPD RI dan, DRSP Indonesia, 2010, Mengatur Pemilukada Naskah Akademis PokokPokok Pikiran Pembentukan Undang-Undang tentang Pemilihan Umum Kepala Daerah

Easton, David, 1957, An Approach to the Analysis of Political Systems, World Politics, Vol. 9, No. 3, April

Firmanzah, 2008, Mengelola Partai Politik Komunikasi dan Positioning Ideologi Politik di Era Demokrasi, Jakarta, Yayasan Obor Indonesia.

Gaffar, Afan, 1999, Politik Indonesia, Transisi Menuju Demokrasi, Cetakan I, Yogyakarta, Penerbit Pustaka Pelajar

Hidayat, Syarif, 2000, Refleksi Realitas Otonomi Daerah dan Tantangan ke Depan, Jakarta:

Pustaka Quantum,.

International IDEA, 2000, Penilaian Demokrasi di Indonesia, Pengembangan Kapasitas Seri 8

Isaak, Alan, C. 1981, Scope and Methods of Political Science, An Introduction to The Methodology of Political Inquiry, Third edition, Homewood Illinois, The Dorsey Press

Kantapawira, Rusadi, 1980, Sistem Politik Indonesia, Suatu Model Pengantar, Bandung, Penerbit Sinar Baru

Kristiadi, J, 2009, Dominasi Parpol dalam Pilkada Menuju Terwujudnya Sistem Partai Kartel?, Opini, Kompas, 5 Mei

Liddle, Wiiliam, R., 1992, Pemilu-Pemilu Orde Baru, Pasang Surut Kekuasaan Politik, Jakarta, Penerbit LP3ES

Lipset, S.M., 1993, The Social Requisites of Democracy Revisited: Presidential Address', dalam, American Sociological Review, vol. 59, no.1

Norris, Pippa, 2004, Building political parties: Reforming legal regulations and internal rules, Harvard University Report commissioned by International IDEA

-------, 2005, Political Parties and Democracy in Theoretical and Practical Development in Party

Communications, National Democratic Institute for International Affairs (NDI) Nurhasim, Moch., 2005, Pengaruh dan Kekuatan Kyai Dalam Rekrutmen Politik Kasus

Kabupaten Sampang dan Pasuruan, dalam Haris, Syamsuddin (Editor), Pemilu Langsung di Tengah Oligarki Partai proses nominasi dan seleksi calon legislatif Pemilu 2004, Jakarta, Penerbit PT Gramedia Pustaka Utama bekerjasama dengan Lembaga Ilmu Pengetahuan Indonesia (LIPI) dan Netherlands Institute for Multiparty Democracy (IMD)

Panggabean, Samsurizal, 1991, Pemilu dan Demokrasi: Beberapa Catatan Kritis, dalam Prospektif, Kajian Masalah-Masalah Nasional dan Internasional, No. 2, Volume 3 
Scarrow, Susan, 2005, Political Parties and Democracy in Theoretical and Practical Perspectives Implementing Intra-Party Democracy, National Democratic Institute for International Affairs (NDI)

Seda, Francisia, SSE, 2002, "Sistem Rekrutmen Anggota Legislatif dan Pemilihan di Indonesia," in International IDEA, Perempuan di Parlemen: Bukan Sekedar Jumlah, Stockholm: International IDEA.

Shively, W. Philips, 1991, Power and Choice an Introduction to Political Science, Second Edition, New York, McGraw-Hill, Inc.

Supriatma, Antonius Made Tony, 2009, Menguatnya Kartel Politik Para “Bos”, dalam Prisma, Majalah Pemikiran Sosial Ekonomi, Penerbit LP3ES, Vol. 28, No. 2

Surbakti, Ramlan, 1992, Memahami Ilmu Politik, Jakarta, Penerbit PT Gramedia Widiasarana Indonesia

Tryatmoko, Mardyanto Wahyu, 2006, Pilkada Langsung 2005: Peran Partai Politik dalam Pencalonan Kepala Daerah, ISSN 1441-7923: WIDYARISET Vol. 9, No. 2, Penerbit Lembaga Ilmu Pengetahuan Indonesia, hal. 197 - 205 